\title{
Pengaruh Pemberian Bubur Labu Kuning dan Daging Ayam Terhadap Peningkatan BB pada Bayi Gizi Kurang
}

\author{
Yusni Podungge ${ }^{1)}$ dan Puspita Sukmawaty Rasyid2) \\ 1Jurusan Kebidanan Politekhnik Kesehatan Kemenkes Gorontalo \\ email: nunifay@yahoo.co.id \\ 2Jurusan Kebidanan Politekhnik Kesehatan Kemenkes Gorontalo \\ emai: alif_puspita@yahoo.co.id
}

\begin{abstract}
Undernutrition in infants is a condition where the baby does not grow and develop optimally because of the unfulfilled intake of nutrition substances in the body. Under-nutrition in infants can be overcome by the provision of balanced nutritious foods, one sign of improved nutrition can be seen from normal weight gain for age. One of the foods that can boost the improvement of nutrients is a food that contains proteins and vitamins, such as yellow pumpkin and chicken, where yellow pumpkin contains vitamin $A$ and chicken meat as a source of animal protein that contains good nutrients. The purpose of this study was to analyze the effect of yellow pumpkin and chicken meat on weight growing infant 12 months in work area of Talaga Jaya Community Health Center. The research method used experimental research model with design non equivalent control group for each group of intervention and control. Sampling using purposive sampling according to inclusion and exclusion criteria. With a sample number of 30 malnourished infants less than 12 months of age. Analytical techniques was used in the chi square test. The result of this research was showed that value of chi square count 22,634 highger than chi square table $D f 1=3,841$. There was influence giving yellow pumpkin pumper and chicken to enhancement nutritional weight infant weight 12 month in work area Puskesmas Talaga Jaya. The conclusion was the provision of pumpkin porridge can raise the weight of infants less than 12 months of age as a benchmark nutritional improvements in infants less nutrition.
\end{abstract}

Keywords: yellow pumpkin, chicken meat, undernutrition

\section{PENDAHULUAN}

Menurut United Nations Children's Emergency Fund (UNICEF), kekurangan gizi pada balita menempati urutan keempat masalah pada balita setelah campak, diare dan infeksi saluran pernafasan. Kekurangan gizi timbul karena tidak adanya sumber makanan, pasokan makanan terhambat, dan wabah diare yang dapat mengganggu saluran pencernaan sehingga menurunkan nafsu makan.

Secara nasional,prevalensi gizi buruk dan kurang pada anak balita sebesar 19,6\%, sedangkan sasaran Sustainable Development Goals (SDGs) tahun 2019 yaitu 17\%. Oleh karena itu, prevalensi gizi buruk dan kurang secara nasional harus 
Podungge, dkk

diturunkan sebesar 2,6\% dalam periode 2015 sampai 2019.Diantara 33 provinsi di Indonesia,18 provinsi memiliki prevalensi gizi buruk-kurang di atas angka prevalensi nasional yakni berkisar antara 21,2\% sampai dengan 33,1\% yaitu urutan yang pertama adalah Nusa Tenggara Timur dan Gorontalo berada di urutan yang kedelapan (Profil Kesehatan Indonesia, 2013).

Provinsi Gorontalo pada tahun 2015 diketahui bahwa presentase balita dengan gizi kurang mencapai (18,8 \%) dengan kasus gizi kurang tertinggi adalah Kabupaten Bualemo sebesar $(30,8 \%)$ dan tertinggi kedua adalah Kabupaten Gorontalo sebesar 19,8\%. Dan pada tahun 2016 presentasi kasus gizi kurang di Provinsi Gorontalo mencapai $(17,69)$, daerah dengan kasus gizi kurang tertinggi adalah Kabupaten Pohuwato sebesar $(23,46 \%)$ dan terendah Kota Gorontalo sebesar(13,8\%) (PSG Provinsi Gorontalo, 2016).

Berdasarkan hasil wawancara awal yang di lakukan di Puskesmas Talaga Jaya masalah gizi yang meningkat dipengaruhi oleh pola asuh keluarga, ekonomi dan pendidikan ibu yang rendah sehingga menyebabkan kurangnya pengetahuan ibu untuk mengelola Mp-ASI (makanan pendamping ASI) yang bergizi bagi bayinya.

Masa balita merupakan masa pertumbuhan dan perkembangan sehingga merupakan masa yang cukup penting. Asupan makanan yang di butuhkan harus di perhatikan misalnya dengan memberikan makanan yang bergizi. Makanan yang diberikan pada bayi dan anak akan di gunakan untuk pertumbuhan badan, karena itu status gizi dan pertumbuhan dapat dipakai sebagai ukuran untuk memantau cakupan gizi bayi (Irianto, 2014).

Hasil penelitian Hasri Kusumawati labu kuning mengandung Betakaroten pro vitamin A yang dapat berperan dalam perkembangan penglihatan anak, pertumbuhan tulang dan gigi dan berperan dalam regulasi sistem kekebalan tubuh sedangkan ikan gabus merupakan ikan air tawar yang tinggi protein berperan dalam pertumbuhan jaringan pemeliharaan sel dan keperluan lain di dalam tubuh sehingga dapat meningkatkan status gizi pada bayi ketika di kelola sebagai MP-ASI. Ikan gabus sebagai ikan air tawar sekarang sudah sangat sulit ditemui dan harganya sudah sangat mahal bagi masyarakat di pedesaan. Sumber protein yang hampir sama terdapat pada daging ayam yaitu $(18,2 \%)$. Daging ayam juga mengandung vitamin dan mineral yang baik bagi bayi. Mineral yang baik pada daging ayam dapat membentuk sistem kekebalan tubuh yang dapat menghindari bayi dari penyakit infeksi.

Berdasarkan uraian masalah diatas maka tujuan penelitian ini adalah untuk mengetahui pengaruh pemberian bubur labu kuning dan daging ayam terhadap peningkatan berat badanbayi gizi kurang usia 12 Bulan di Puskesmas Talaga Jaya.

\section{METODE PENELITIAN}

Jenis penelitian yang peneliti gunakan yaitu quasi eksperimen design yang bersifat non equivalent control group, dalam penelitian ini penelitian 
ingin menganalisis pengaruh pemberian bubur labu kuning dan daging ayam sebagai makanan pen damping ASI terhadap peningkatanberat badan bayi gizi kurang di wilayah kerja Puskesmas Talaga Jaya, dimana peneliti meneliti dua kelompok yang digunakan untuk penelitian, kelompok eksperimendan kelompok kontroldilakukan observasi pertama (pretest) yang memungkinkan menguji perubahan-perubahan yang terjadi setelah diberi intervensi pada kelompok eksperimen, hasil observasi kemudian di kontrol atau di bandingkan dengan hasil observasi pada kelompok kontrol yang tidak menerima program atau intervensi (Notoatmodjo, 2012).

Penelitian ini dilaksanakan sejak 2 minggu yaitu pada tanggal 23Mei sampai dengan 6 Juni 2017 diwilayah kerja Puskesmas Talaga Jaya. Variabel penelitian yaitu Bubur Labu kuning dan daging ayam (Variabel bebas), dan Peningkatan berat badan bayi gizi kurang (Variabel terikat).

Populasi dalam penelitian ini adalah seluruh bayi gizi kurang diwilayah kerja Puskesmas Talaga Jaya sebanyak 42bayi. Sampel penelitian ini adalah 30 bayi usia12 bulan penderita gizi kurang dibagi menjadi 15 bayi yang di berikan perlakuan dan 15 bayi yang tidak di berikan perlakuan dari 42 bayi gizi kurang yang berada di wilayah kerja Puskesmas Talaga Jayadengan menggunakan teknik purposive sampling yaitu didasarkan pada suatu pertimbangan tertentu yang dibuat oleh peneliti sendiri, berdasarkan ciri atau sifat-sifat populasi yang sudah di ketahui sebelumnya (Notoatmodjo, 2012). Dengan Kriteria Inklusi adalah bayi usia 12 bulan yang bersedia menjadi responden.

Instrumen penelitian yang digunakan adalah lembar observasi (check list) yaitu suatu daftar pengecek berisi nama subyek, dan beberapa gejala/identitas lainnya dari sasaran pengamatan. Pengamat tinggal memberikan tanda check (v) pada daftar tersebut yang menunjukan adanya gejala/ciri dari sasaran pengamatan (Notoatmodjo, 2012). Sedangkan untuk mendapatkan hasil peningkatan berat badan peneliti menggunakan timbangan berat badan bayi, yaitu alat mekanik untuk mengukur berat badan bayi yang telah di kalibrasikan terlebih dahulu. peningkatan berat badan responden pada kelompok eksperimen diukur sebelum dan sesudah diberikanbubur labu kuning dan daging Ayam, kemudian hasilnya di catat pada lembar hasil pengukuran.

\section{HASIL DAN PEMBAHASAN}

Responden dalam penelitian ini adalah 15 bayi gizi kurang usia 12 bulan yang mendapatkan intervensi dan 15 bayi gizi kurang usia 12 bulan sebagai kelompok kontrol di wilayah kerja Puskesmas Talaga Jaya Kabupaten Gorontalo tahun 2017. Hasil penelitian ini didapatkan ada kenaikkan berat badan bayi yang dijadikan kelompok kontrol mencapai angka mean 6500.00 dalam 2 minggu penelitian mencapai 6586.67, ada kenaikkan 86.67. hal ini menunjukan bahwa kelompok kontol juga mengalami kenaikkan berat badan tetapi tidak sesignifikan kelompok

intervensi, di mana kelompok intervensi mencapai kenaikkan 193.34 
Podungge.dkk

Tabel 1. Distribusi Sampel Menurut Jenis Kelamin Di Wilayah Kerja Puskesmas Talaga Jaya Kabupaten Gorontalo

\begin{tabular}{llll}
\hline No & Jenis Kelamin & $\mathrm{n}$ & $\%$ \\
\hline 1 & Laki-laki & 12 & 40,0 \\
2 & Perempuan & 18 & 60,0 \\
\hline & Jumlah & 30 & 100 \\
\hline
\end{tabular}

Berdasarkan tabel diatas diketahui bahwa responden bayi di Kecamatan Talaga Jaya Kabupaten Gorontalo dalam penelitian ini didominasi oleh perempuan $60 \%$ sedangkan laki-laki 40\%.

Tabel 2. Kenaikkan berat badan sebelum dan sesudah kelompok intervensi dan kelompok kontrol di Wilayah Kerja Puskesmas Talaga Jaya

\begin{tabular}{ccc}
\hline \multirow{2}{*}{ Berat Badan } & Intervensi & Kontrol \\
\cline { 2 - 3 } & Mean & Mean \\
\hline BB sebelum pemberian $(\mathrm{gr})$ & 6513.33 & 6500.00 \\
BB setelah pemberian $(\mathrm{gr})$ & 6706.67 & 6586.67 \\
\hline
\end{tabular}

Berdasarkan tabel di atas menunjukan bahwa kenaikkan berat badan bayi yang diberikan intervensi sebelum pemberian bubur labu kuning mencapai angka mean 6513.33 dan sesudah pemberian mencapai angka mean 6706.67 dalam periode 2 minggu penelitian, ada kenaikan mencapai 193,34 berat badan.

Tabel diatas juga menunjukan bahwa ada kenaikkan berat badan bayi yang dijadikan kelompok kontrol mencapai angka mean 6500.00 dalam 2 minggu penelitian mencapai 6586.67, ada kenaikkan 86.67. hal ini menunjukan bahwa kelompok kontol juga mengalami kenaikkan berat badan tetapi tidak sesignifikan kelompok intervensi, di mana kelompok intervensi mencapai kenaikkan 193.34.

Tabel 3.Pengaruh pemberian bubur labu kuning dan daging ayam terhadap kenaikkan berat badan bayi gizi kurang usia 12 bulan Di Wilayah Kerja Puskesmas Talaga Jaya.

\begin{tabular}{lccccc}
\hline \multirow{2}{*}{ Berat Badan } & \multicolumn{2}{c}{ Diberikan } & \multicolumn{2}{c}{ Tidak diberikan } & \multirow{2}{*}{ p value } \\
\cline { 2 - 5 } & $\mathrm{n}$ & $\%$ & $\mathrm{n}$ & $\%$ & \\
\hline Naik & 14 & 93,3 & 0 & 0 & \multirow{2}{*}{0.000} \\
Tidak naik & 1 & 6,7 & 15 & 100 & \\
\hline \multicolumn{1}{c}{ Total } & 15 & 100 & 15 & 100 & \\
\hline
\end{tabular}

Berdasarkan tabel diatas setelah 14 hari pemberian bubur labu kuning dan daging ayam didapatkan hasil berat badan pada 15 bayi kelompok intervensi, ada 14 bayi yang mengalami peningkatan berat badan, jika di presentasikan rata-rata 93.3\% responden mengalami peningkatan berat badan, dan hanya ada 1 bayi dengan rata-rata $6,7 \%$ yang tidak mengalami peningkatan berat badan yang mencapai batas normal kenaikkan berat badan pada usia 12 bulan. Hasil uji statistik menggunakan uji chi square di dapatkan nilai chi square hitung 22.634, sedangkan berdasrkan $\mathrm{df}=1$ harga chi square tabel $=3.841$. Sesuai ketentuan jika harga chi square hitung lebih besar dari tabel makan HO di tolak dan Ha di terima. 
Artinya ada pengaruh pemberian bubur labu kuning dan daging ayam terhadap peningkatan berat badan bayi gizi kurang usia 12 bulan.

Hasil penelitian ini sejalan dengan penelitian yang dilakukan oleh Kusumawati (2015), yaitu di dapatkan terdapat perbedaan secara bermakna $(p<0,05)$ asupan energi, karbohidrat, lemak dan protein sebelum dan setelah pemberian MP-ASI bubur instan berbasis ikan gabus dan labu kuning. Ada pengaruh yang signifikan baik asupan intervensi maupun asupan selain intervensi terhadap asupan setelah intervensi $(\mathrm{p}<0,05)$.

Penelitian ini membuktikan teori sebelumnya yang menyatakan, bubur labu kuning adalah bubur bayi yang kaya vitamin A untuk kesehatan mata si kecil, dan mengandung vitamin $\mathrm{C}$ dan serat. Karena vitamin A dalam labu kuning dapat meningkatkan kerentanan terhadap infeksi maka dapat memulihkan keadaan tubuh bayi penderita gizi kurang yang dapat membentuk kembali sistem imunitas bayi. Oleh karena itu pangan tinggi beta karoten baik untuk meningkatkan status vitamin A dan mengurangi kejadian infeksi pada anak dengan malnutrisi berat yang dapat menyebabkan gizi buruk jika tidak ditangani dengan baik (Hurul, 2015). Vitamin A dibutuhkan untuk perkembangan tulang dan sel epitel yang membentuk email dalam pertumbuhan gigi. Pada kekurangan vitamin A, pertumbuhan tulang terhambat dan bentuk tulang tidak normal. Pada anak-anak yang kekurangan vitamin A, terjadi kegagalan dalam pertumbuhan.

Bubur labu kuning yang di konsumsi dengan daging ayam akan sangat baik untuk perbaikkan gizi pada bayi gizi kurang karena Vitamin A dalam labu kuning berpengaruh terhadap sintesis protein yang terdapat pada daging ayam, sehingga dapat berdampak terhadap pertumbuhan sel. Dalam labu kuning vitamin A berperan penting dalam regulasi sistem kekebalan tubuh, sehingga defisiensi vitamin A dapat meningkatkan kerentanan terhadap infeksi (Hurul, 2015).

Bubur labu kuning yang kaya vitamin A juga merupakan faktor esensial untuk perkembangan sistem limpoid dan perkembangan permukaan mukosa saluran pencernaan, pernapasan dan genitourinary dan berperan dalam pembentukan selsel jaringan yang rusak karena adanya kekurangan gizi, sehingga dapat berpengaruh dalam meningkatkan status gizi bayi. Kandungan gizi yang terdapat makan daging ayam sangat baik buat pertambahan masa otot. Manfaat makan daging bagi kesehatan jelas sangat tinggi, karena daging ayam mengandung protein tinggi, serta vitamin dan mineral. Kandungan mineral baik pada daging ayam dapat membentuk sistem kekebalan tubuh yang dapat menghindarkan bayi dari penyakit infeksi. Seperti halnya vitamin A, mineral yang terdapat dalam daging ayam juga dapat membentuk sistem kekebalan tubuh yang dapat mempengaruhi perbaikkan status gizi pada bayi gizi kurang.

Protein untuk balita berperan dalam pertumbuhan, pemeliharaan sel, mengganti jaringan rusak dan deposit jaringan otot. Tubuh akan memecah protein dalam darah dan jaringan menjadi asam amino dan kemudian mengubahnya menjadi glukosa. Jika tubuh menggunakan protein untuk energi, maka protein tidak dapat digunakan untuk fungsi-fungsi yang lain. Dan karbohidrat akan berfungsi memusatkan protein pada fungsinya. 
Podungge, dkk

Asupan gizi yang baik bagi balita juga terdapat pada makanan yang mengandung protein. Karena protein sendiri bermanfaat sebagai prekursor untuk neurotransmitter demi perkembangan otak yang baik nantinya. Protein diperlukan untuk pertumbuhan dan pemeliharaan dan perbaikan jaringan tubuh, serta untuk membuat enzim pencernaan dan zat kekebalan yang bekerja untuk melindungi tubuh si kecil. Kebutuhan protein secara proporsional lebih tinggi untuk anakanak dari pada orang dewasa.

Sebelum sel-sel dapat mensintesis protein baru, harus tersedia asam amino esensial yang diperlukan dan cukup nitrogen atau ikatan amino (NH2) guna pembentukan asam-asam amino nonesensial yang diperlukan. Pertumbuhan atau penambahan otot hanya mungkin bila tersedia cukup campuran asam amino yang sesuai termasuk untuk pemeliharaan dan perbaikan. Protein kolagen merupakan protein utama otot, tendo dan jaringan ikat.

Sehingga ketika bayi mengonsumsi labu kuning dan daging ayam terdapat zatzat gizi yang baik masuk kedalam tubuh bayi, yang dapat memperbaiki status gizi pada bayi gizi kurang. Adanya Vitamin dan protein yang masuk dapat memperbaiki jaringan sel-sel yang rusak karena adanya kekurangan gizi sebelumnya.

Menurut asumsi peneliti 1 responden tidak mengalami peningkatan berat sesuai dengan batas normal kenaikkan berat badan, karena ada faktor-faktor yang mempengaruhi yaitu pola dan pola asuh asuh orang tua yang masih sangat kurang dalam memperhatikkan anaknya, selain itu nafsu makan anak yang cenderung kurang karena anak merasa ketidaknyamanan dalam waktu makannya. Teori ini di dukung oleh teori (Irianto, 2014) pola asuh terhadap anak berpengaruh dalam masalan gizi, karena setiap anak membutuhkan cinta, perhatian dan kasih sayang yang berdampak terhadap perkembangan fisik mental dan emosial. Perdani dkk 2016 mendefinisikan tekanan untuk makan sebagai tindakan mendorong anak untuk makan. Orang tua sering sekali melakukan tindakan tekanan pada anak dalam aktivitas makan untuk usaha meningkatkan berat badan anak. Bentuk lain dari tekanan yang seringkali dilakukan orangtua adalah dengan membentak, berkata kasar, memaksa anak untuk makan makanan yang disediakan. Tekanan yang dilakukan orangtua agar anak mau makan atau menghabiskan makanannya akan menggangu psikologis anak. Anak akan merasa bahwa aktivitas makan merupakan aktivitas yang tidak menyenangkan sehingga anak akan kehilangan nafsu makan yang akan berdampak pada pertumbuhannya.

Menurut penelitian yang dilakukan oleh Mascola Dkk dalam Putri dkk (2015), bahwa anak meniru perilaku orangtua yang seringkali memilih-milih makanan berdasarkan selera (kesukaan). Sebaliknya, jika orang tua mengkonsumsi banyak sayur dan buah dan menghindari konsumsi makanan tidak sehat dihadapan anak-anaknya maka akan mengurangi resiko anak dalam konsumsi makanan yang tidak sehat.

Menurut peneliti upaya yang harus dilakukan ibu dalam menyediakan MP-ASI, ibu harus dapat membuat waktu makan itu menjadi waktu yang menyenangkan dengan tidak membentak dan memaksakan anak untuk makan, buat makananmakanan yang lebih bervariasi dan menarik buat bayi. Jadikan lingkungan rumah 
menjadi lingkungan ternyaman bayi dan hindarkan bayi dari makanan-makanan instan dan jajanan yang tanpa kalori agar bayi terbiasa makan-makanan yang bergizi.

\section{KESIMPULAN DAN SARAN}

Ada pengaruh pemberian bubur labu kuning dan daging ayam terhadap peningkatan berat badan bayi gizi kurang usia 12 bulan di wilayah kerja Puskesmas Talaga Jaya. Ada peningkatan berat badan bayi gizi kurang usia 12 bulan karena pemberian bubur labu kuning dan daging ayam yang mengandung protein dan vitamin A yang berperan dalam sistem kekebalan tubuh dan memperbaiki sel - sel tubuh bayi yang rusak sehingga dapat memperbaikki status gizi bayi sehingga dapat meningkatkan berat badan bayi gizi kurangHasil penelitian agar dapat menambah pengetahuan ibu yang memiliki bayi gizi kurang dalam membuat variasi Mp-ASI yang bergizi baik dari pangan-pangan lokal, selain harganya terjangkau pangan lokal dapat di jadikan tanaman keluarga.

\section{REFRENSI}

Departemen Kesehatan . 2013. Profil Kesehatan Indonesia. Jakarta

Hurul. 2015. Perbedaan Asupan Vitamin A Dan Seng Sebelum Dan Setelah Pemberian Makanan Pendamping ASI (MP-ASI) Bubur Instan Berbasis Ikan Gabus Dan Labu Kuning Pada Balita Gizi Kurang. Artikel Penelitian. Fakultas Kedokteran Universitas Dipenogoro. Semarang.

Kusumawati. 2015. Perbedaan Asupan Gizi Makro Sebelum Dan Setelah Pemberian Makanan Pendamping ASI (MP-ASI) Bubur Instan Berbasis Ikan Gabus Dan Labu Kuning Pada Balita Gizi Kurang. Skripsi. Semarang.

PSG. 2016. Pemantauan Status Gizi Provinsi Gorontalo, Gorontalo

Irianto. 2014. Gizi Seimbang Dalam Kesehatan Reproduksi. Alfabeta. Bandung.

Notoatmodjo S. 2012. Metode Penelitian Kesehatan. Rineka Cipta. Jakarta

Perdani ZP, R Hasan, N Nurhasanah. 2016. Hubungan Praktik Pemberian Makan Dengan Status Gizi Anak Usia 3-5 Tahun Di Pos Gizi Desa Tegal Kunir Lor Mauk Taggerang. JKFT, Edisi Nomor 2, Januari 2016

Putri W. 2015. Hubungan Kontrol Makanan, Model Peran Dan Keterlibatan Anak Dengan Sulit Makan Pada Anak. Jurnal Keperawatan Sriwijaya, Volume 2 Nomor 1, Januari 2015, ISSN No 23555459 Palembang. 